\title{
PENGARUH SELF EFFICACY DAN KECERDASAN EMOSI TERHADAP MOTIVASI BERPRESTASI SISWA SMK PGRI 1 MADIUN
}

\author{
Wahyu Puji Lestari *) \\ Dian Ratnaningtyas Afifah **)
}

\begin{abstract}
ABSTRAK
Pelaksanaan pembelajaran di SMK PGRI 1 Madiun disajikan dengan metode ceramah dan kurang memberi kesempatan siswa untuk aktif, sehingga motivasi siswa dalam belajar cenderung rendah. Hal ini ditunjukkan dengan sikap siswa yang sering tidak mengikuti pelajaran, sering tidur dikelas, dan jarang mengerjakan tugas yang diberikan oleh guru bidang studi. Maka dari itu peneliti berusaha untuk menumbuhkan keyakinan diri siswa dalam menghadapi situasi tertentu. Self Efficacy diharapkan menjadi strategi yang tepat dalam menumbuhkan keyakinan dalam diri siswa untuk selalu berpikir positif serta mampu mengendalikan emosi, sehingga dapat memunculkan kemauan untuk termotivasi berprestasi sebagai langkah awal siswa untuk menuju kessuksesan belajar.

Penelitian ini bertujuan untuk mengetahui pengaruh self efficacy dengan kecerdasan emosi, baik bersama-sama maupun secara mandiri terhadap motivasi berprestasi siswa SMK PGRI 1 Madiun.

Peneliti menggunakan metode deskripsi korelasional ex-post facto dan penentuan sampel dalam penelitian ini menggunakan teknik random sampling yaitu sebanyak 97 siswa dari jumlah semua populasi siswa SMK PGRI 1 Madiun yang berjumlah 152 siswa. Pengumpulan data menggunakan metode skala psikologi. Dalam menganalisis data menggunakan statistik regresi dua predictor dan Uji F.

Hasil penelitian menunjukkan: 1) Ada pengaruh self efficacy terhadap motivasi berprestasi pada siswa SMK PGRI 1 Madiun. 2) Ada pengaruh kecerdasan emosi terhadap motivasi berprestasi pada siswa SMK PGRI 1 Madiun. 3) Ada pengaruh self efficacy dan kecerdasan emosi terhadap motivasi berprestasi siswa SMK PGRI 1 Madiun.
\end{abstract}

Kata Kunci : Self Efficacy, Kecerdasan Emosi, Motivasi Berprestasi.

\footnotetext{
* Wahyu Puji Lestari adalah Mahasiswa Program Studi Bimbingan dan Konseling Fakultas Ilmu Pendidikan IKIP PGRI Madiun.

** Dian Ratnaningtyas Afifah adalah Dosen Program Studi Bimbingan dan Konseling Fakultas Ilmu Pendidikan IKIP PGRI Madiun.
} 


\section{A. PENDAHULUAN}

Kesuksesan siswa dalam dunia pendidikan selalu dikaitkan dengan motivasi. Motivasi merupakan salah satu aspek psikologis yang mendorong individu untuk memilih, melaksanakan, dan mengarahkan aktivitasnya. John W. Santrock (2003: 474) menyatakan bahwa motivasi berprestasi merupakan suatu keinginan untuk menyelesaikan sesuatu, untuk mencapai suatu standar kesuksesan, dan untuk melakukan suatu usaha dengan tujuan untuk mencapai kesuksesan. Semakin kuat motivasi seseorang semakin besar kemungkinan nya untuk berhasil melaksanakan satu kegiatan atau tugas.

Abdul Rahman Barakatu (2007: 47) menjelaskan bahwa motivasi mendorong dan meningkatkan siswa untuk meniru dan mencontoh perilaku seseorang. Salah satu alasan siswa tergerak untuk meniru model karena mereka merasa bahwa dengan berbuat demikian akan meningkatkan peluang untuk mendapatkan insentif atau reinfors.

Di dalam kelas, motivasi ini lebih sering didorong dengan pemberian pujian dan nilai positif. Insentif yang diberikan kepada siswa yang mengarahkan perhatian kepada seseorang, mempraktekkannya, dan mereproduksikan kembali kecakapannya karena mereka sudah mempelajarinya sesuai apa yang diinginkan dan disenangi guru sehingga mereka mendapatkan reinfors akan memperkuat keinginan siswa untuk meraih prestasi yang baik. Dorongan, sambutan hangat, penghargaan, dan pengakuan akan menumbuhkan self efficacy dan motivasi internal yang sangat bermanfaat dalam kegiatan belajar berikutnya.

Abdul Rahman Barakatu (2007: 48) mengemukakan keterkaitan antara motivasi berprestasi dengan self efficacy yaitu pribadi yang memiliki self efficacy positif cenderung mempunyai motivasi yang lebih besar untuk melaksanakan tugas sesuai kriteria standar yang ditetapkan. Keyakinan akan kemampuan diri mendorong individu berbuat lebih efektif dengan memilih langkah-langkah dan cara-cara yang akan ditempuh dalam menyelesaikan suatu tugas atau pekerjaan. Semakin tinggi self efficacy seseorang semakin kuat motivasinya untuk berprestasi. 
Abdul Rahman Barakatu (2007: 41) menyatakan bahwa Self efficacy merupakan unsur pokok dalam menunjang kebutuhan mencapai kesuksesan. Tanpa self efficacy yang positif manusia cenderung mengalami kegagalan apalagi bila tugas itu merupakan tantangan yang besar atau mempunyai resiko yang berat. Bandura dkk (dalam Abdul Rahman Barakatu, 2007: 41) menunjukkan bahwa ekspektasi self efficacy yang rendah merupakan aspek sentral kegagalan untuk mengatasi secara efektif situasi yang membahayakan. Efikasi diri menekankan pada komponen keyakinan diri yang dimiliki seseorang dalam menghadapi situasi yang akan datang yang tidak dapat diketahui dan sering penuh dengan tekanan.

Kecerdasan emosi sangat penting bagi keberhasilan siswa dalam menghadapi tekanan-tekanan tertentu. Karena itu, siswa harus dibekali dan diajarkan bagaimana agar siswa memiliki tingkat kecerdasan emosional yang baik. Goleman (dalam Imam Musbikin, 2013: 85) menjelaskan bahwa kecerdasan emosional adalah kemampuan yang mencakup kemampuan untuk memotivasi diri sendiri dan bertahan menghadapi frustasi; mengendalikan dorongan hati, dan tidak melebih-lebihkan kesenangan; mengatur suasana hati, dan menjaga beban stress tidak melumpuhkan kemampuan berfikir; bersimpati dan berdoa. Siswa yang mampu mempersepsi emosi diri adalah siswa yang mampu mengetahui dan menangani emosi mereka sendiri, serta mampu membaca dan menghadapi emosi orang lain dengan efektif.

Ratna Wulan (2011: 17) mengemukakan keterkaitan antara motivasi dengan kecerdasan emosi, dimana motivasi berkaitan dengan kemampuan seseorang untuk menata emosinya, memusatkan perhatian pada perasaan yang positif dan mengesampingkan perasaan yang bersifat negatif. Meskipun sedang menghadapi masalah, seseorang yang cerdas emosinya akan lebih mengaktifkan rasa semangat dan keyakinan diri dan melumpuhkan perasaan murung, depresi dan sebagainya yang justru akan menghambat aktivitasnya.

Uraian diatas pada dasarnya kondisi yang ideal, kondisi di SMK PGRI 1 Madiun berdasarkan hasil wawancara dengan guru bimbingan dan konseling, masih cukup banyak siswa yang menunjukkan motivasi berprestasinya rendah. Hal ini ditunjukkan dengan sikap siswa yang sering 
tidak mengikuti pelajaran, sering tidur dikelas, dan jarang mengerjakan tugas yang diberikan oleh guru bidang studi.

Dilihat dari pengertian self efficacy dan aspek-aspek didalamnya. peneliti menyimpulkan bahwa sikap siswa yang seperti itu diakibatkan self efficacy yang sangat rendah sehingga kecerdasan emosi siswa tidak dapat berkembang dengan baik serta tidak adanya motivasi dari dalam maupun dari luar diri siswa yang mendorong untuk tetap optimis dalam menghadapi suatu permasalahan yang ada. Akibat yang ditimbulkan dari permasalah diatas yaitu rendahnya prestasi siswa di sekolah.

\section{B. KAJIAN TEORI}

\section{Self Efficacy}

Albert Bandura (dalam David G. Myers, 2012: 72) mengemukakan bahwa self efficacy merupakan perasaan akan kemampuan kita dalam mengerjakan suatu tugas.

Bandura (dalam M. Nur Ghufron \& Rini Risnawati S, 2010: 73) mendefinisikan bahwa efikasi diri (self efficacy) adalah keyakinan individu mengenai kemampuan dirinya dalam melakukan tugas atau tindakan yang diperlukan untuk mencapai hasil tertentu.

Laura A. King (2012: 412) mengemukakan self efficacy adalah kepercayaan individu bahwa ia dapat menuasai sebuah situasi dan menghasilkan keluaran yang positif.

Dede Rahmat Hidayat (2011: 156) menyatakan bahwa efikasi diri adalah penilaian diri terhadap kemampuan diri untuk mengatur dan melaksanakan tindakan yang diperlukan untuk mencapai kinerja yang ditetapkan. Efikasi diri memberikan dasar bagi motivasi manusia, kesejahteraan, dan prestasi pribadi.

Kreitner \& Kinicki (dalam Harfiahana Puspa Sari, 2013: 35) mengemukakan self efficacy sebagai keyakinan seseorang mengenai peluangnya untuk berhasil mencapai tugas tertentu.

Berdasarkan beberapa pengertian diatas maka peneliti berpendapat bahwa self efficacy (efikasi diri) adalah kesanggupan seseorang untuk 
dapat menguasai situasi yang tidak menyenangkan dan penuh dengan tekanan kemudian berusaha untuk meyakinkan diri sesuai dengan penilaian diri terhadap kemampuan diri untuk mengatur dan melaksanakan tindakan agar dapat mengubah suatu situasi dan mampu menghasilkan berbagai hasil positif.

\section{Kecerdasan Emosi}

Daniel Goleman (2005: 45) mendefinisikan kecerdasan emosional merupakan kemampuan seperti kemampuan untuk memotivasi diri sendiri dan bertahan menghadapi frustasi, mengendalikan dorongan hati dan tidak melebih-lebihkan kesenangan, mengatur suasana hati dan menjaga agar beban stres tidak melumpuhkan kemampuan berpikir, berempati dan berdoa.

Peter Solvey dan John Mayer (dalam Imam Musbikin, 2013: 83) mendifisikan kecerdasan emosional sebagai berikut: emotional intelligence involves the ability to perceive accurately, appraise, and express emotion, the ability to access and/or generate feelings when they facilitate thought, the ability to understand emotion and emotional knowledge, and ability to regulate emotions to promote emotional and intellectual growth. (kecerdasan emosional melibatkan kemampuan untuk memahami secara akurat, menilai, dan mengekspresikan emosi, kemampuan untuk mengakses dan / atau menghasilkan perasaan ketika mereka memfasilitasi pemikiran, kemampuan untuk memahami emosi dan pengetahuan emosional, dan kemampuan untuk mengatur emosi untuk meningkatkan pertumbuhan emosional dan intelektual).

Cooper dan Sawaf (dalam Makmum Khairani, 2013: 160) mengemukakan bahwa kecerdasan emosi adalah kemampuan merasakan, memahami, dan secara selektif menerapkan daya dan kepekaan emosi sebagai sumber energy dan pengaruh yang manusiawi.

Yatim Riyanto (dalam V. Teguh Suharto, 2011: 142) mengemukakan bahwa kecerdasan emosional adalah kemampuan individu dalam menggunakan (mengelola) emosinya secara efektif untuk 
mencapai tujuan, membangun hubungan yang produktif dengan orang lain dan meraih keberhasilan.

Imam Musbikin (2013: 100) menjelaskan bahwa kecerdasan emosi adalah kemampuan mengenali perasaan diri, kemampuan memahami emosi orang lain, serta dalam menggunakan emosi tersebut.

Dari beberapa definisi yang telah dikemukakan diatas, maka peneliti dapat menarik kesimpulan bahwa kecerdasan emosional merupakan kemampuan yang dimiliki individu untuk merasakan, menilai, memahami, dan mengatur kehidupan emosinya serta menjaga keselarasan emosi agar dapat memotivasi diri, mengendalikan diri, dan dapat mengatur keadaan jiwa.

\section{Motivasi Berprestasi}

J.P Chaplin (dalam Singgih D. Gunarsa, 2004: 141) mengemukakan dorongan berprestasi sebagai berikut:

1) Kecenderungan untuk mencapai sukses atau memperoleh apa yang menjadi tujuan akhir yang dikehendaki

2) Keterlibatan diri seseorang terhadap suatu tugas

3) Harapan untuk berhasil dalam suatu tugas yang diberikan

4) Dorongan untuk mengatasi rintangan-rintangan atau perjuangan untuk melakukan pekerjaan-pekerjaan yang sulit secara cepat dan tepat.

John W Santrock (2003: 474) berpendapat bahwa motivasi berprestasi (achievement motivation) adalah keinginan untuk menyelesaikan sesuatu, untuk mencapai suatu standar kesuksesan dan untuk melakukan suatu usaha dengan tujuan untuk mencapai suatu kesuksesan.

Sofyan S. Wilis (2012: 72) mendefinisikan bahwa motif berprestasi adalah suatu dorongan dari dalam diri untuk selalu meraih prestasi.

Djaali (2012: 107) mengemukakan bahwa motivasi berprestasi dapat diartikan dorongan untuk mengerjakan suatu tugas dengan sebaikbaiknya berdasarkan standar keunggulan. 
Hilgard (dalam Dendik Surya Wardana, 2013: 100) mengemukakan motivasi berprestasi adalah motif sosial untuk mengerjakan sesuatu yang berharga atau penting dengan baik dan sempurna untuk memenuhi standart keunggulan dari apa yang dilakukan seseorang.

Keith \& Nastron (dalam Rumiani, 2006: 39) mendefinisikan motivasi berprestasi sebagai dorongan yang dimiliki oleh seseorang untuk mengatasi hambatan dalam mencapai tujuan, sehingga individu yang memiliki motivasi berprestasi tinggi menunjukkan usaha yang lebih besar dan ulet.

Berdasarkan beberapa definisi tentang motivasi berprestasi maka peneliti berpendapat bahwa motivasi berprestasi adalah suatu dorongan yang ada dalam diri seseorang untuk berusaha dan bekerja keras dalam mengatasi hambatan untuk mencapai tujuan, keberhasilan dan keunggulan, sehingga individu memiliki motivasi berprestasi tinggi yang menunjukkan usaha yang lebih besar dan ulet.

\section{METODE PENELITIAN}

Penelitian ini menggunakan metode deskripsi korelasional ex-post facto. Penggunaan metode ex post facto ini diperkuat oleh pendapat Suharsimi Arikunto (2010: 17) menyatakan ex post facto yaitu suatu penelitian ilmiah yang penelitianya tidak dapat secara langsung memanipulasi dan mengendalikan satu atau lebih variabel bebas serta mengamati variabel terikat untuk melihat perbedaan yang sesuai dengan manipulasi variabel tersebut. Penggunaan metode ini dipandang cukup representatif untuk mengetahui ada atau tidaknya pengaruh antara self efficacy dan kecerdasan emosi terhadap motivasi berprestasi.

Selanjutnya Sugiyono (2012: 80) menjelaskan bahwa populasi adalah wilayah generalisasi yang terdiri atas: obyek/subyek yang mempunyai kualitas dan karakteristik tertentu yang ditetapkan oleh peneliti untuk dipelajari dan kemudian ditarik kesimpulannya. 
Populasi dalam penelitian ini adalah semua siswa SMK PGRI 1 Madiun yang berjumlah 152 siswa.

Sugiyono (2013: 81) menyatakan bahwa sampel adalah bagian dari jumlah dan karakteristik yang dimiliki oleh populasi tersebut. Bila populasi besar, dan peneliti tidak mungkin mempelajari semua yang ada pada populasi, misalnya karena keterbatasan dana, tenaga, dan waktu, maka peneliti dapat menggunakan sampel yang diambil dari populasi itu. Bertolak dari pendapat Sugiyono, sampel yang akan digunakan dalam penelitian ini berjumlah 97 siswa dari jumlah anggota populasi 152 siswa dengan tingkat kesalahan $10 \%$. Hal ini di dukung oleh pendapat dari Sugiyono (2013: 86) yang menyatakan bahwa jumlah anggota sampel sering dinyatakan dengan ukuran sampel. Jumlah sampel diharapkan $100 \%$ mewakili populasi adalah sama dengan jumlah anggota populasi itu sendiri. Makin besar jumlah sampel mendekati populasi, maka peluang kesalahan generalisasi semakin kecil dan sebaliknya makin kecil jumlah sampel menjauhi populasi, maka semakin besar kesalahan generalisasi (diberlakukan umum). Berikut adalah rumus untuk menghitung ukuran sampel dari populasi yang diketahui jumlahnya adalah sebagai berikut

$$
\mathrm{s}=\frac{\lambda^{2} \cdot \mathrm{N} \cdot \mathrm{P} \cdot \mathrm{Q}}{\mathrm{d}^{2}(\mathrm{~N}-1)+\lambda^{2} \cdot \mathrm{P} \cdot \mathrm{Q}}
$$

Keterangan :

$\lambda^{2}$ dengan $\mathrm{dk}=1$, taraf kesalahan bisa $1 \%, 5 \%, 10 \% \cdot \mathrm{P}=\mathrm{Q}=0,5 . \mathrm{d}=0,05 . \mathrm{s}=$ jumlah sampel

Penetapan sampel penelitian menggunakan teknik random sampling agar lebih simple dan sampel yang diteliti sifatnya homogen. Hal ini didukung pendapat Sugiyono (2013: 120) yang mengemukakan teknik random sampling dikatakan simple (sederhana) karena pengambilan anggota sampel dari populasi di lakukan secara acak tanpa memperhatikan strata yang ada dalam populasi itu. Cara demikian dilakukan bila anggota populasi dianggap homogen. Dikatakan homogen karena semua anggota populasi memiliki karakteristik permasalahan yang sama. Penetapan sampel penelitian ini secara metodologi telah memenuhi syarat, karena didukung pendapat Suharsimi Arikunto (2006: 134) yaitu suatu sampel adalah sampel random 
jika tiap-tiap individu dalam populasi diberi kesempatan yang sama untuk ditugaskan menjadi anggota sampel.

Teknik yang digunakan dalam pengumpulan data adalah skala psikologi. Saifudddun Azwar (2011: 03) mengemukakan skala psikologi memiliki karakteristik khusus yang membedakannya dari berbagai bentuk alat pengumpulan data yang lain seperti angket, daftar isian, inventori, dan lainlain. Dalam percakapan sehari-hari istilah skala disama kan dengan istilah tes, namun dalam pengembangan instrumen ukur, umumnya istilah tes digunakan untuk penyebutan alat ukur kemampuan kognitif, sedangkan istilah skala lebih banyak dipakai untuk menamakan alat ukur aspek afektif, maka skala psikologi yang digunakan pada penelitian ini mengacu pada alat ukur aspek atau atribut afektif.

Skala dalam penelitian ini disusun sendiri oleh peneliti dalam bentuk pernyataan. Untuk memudahkan responden dalam menjawab item-item skala, maka peneliti menyusun skala dengan bentuk variasi jawaban yang mempelihatkan tingkat kesetujuan, antara lain adalah : (a) sangat setuju, (b) setuju, (c) tidak setuju, (d) sangat tidak setuju. Secara keseluruhan penyusunan skala ini mengacu pada Skala Likert. Menurut Sugiyono (2012: 93) Skala Likert dipilih karena skala ini digunakan untuk mengukur sikap, pendapat, dan persepsi seseorang atau sekelompok orang tentang fenomena sosial.

Menurut Suharsimi Arikunto (2010: 203) "Instrumen penelitian adalah alat atau fasilitas yang digunakan oleh peneliti dalam mengumpulkan data agar pekerjaannya lebih mudah dan hasilnya lebih baik, dalam arti lebih cermat, lengkap, dan sistematis sehingga lebih mudah diolah".

Uji validitas item angket menggunakan teknik statistik dengan rumus korelasi product-moment. Uji validitas seperti ini didukung oleh pendapat Suharsimi Arikunto (2009: 167) yaitu suatu keadaan yang menggambarkan tingkat instrument yang bersangkutan mampu mengukur apa yang akan diukur. 
a) Uji validitas

Untuk pengujian ini digunakan rumus korelasi product moment dengan angka kasar sebagaimana yang dikemukakan oleh Juliansyah Noor (2011: 169) sebagai berikut:

$$
r_{x y}=\frac{N \sum X Y-\left(\sum X\right)\left(\sum Y\right)}{\sqrt{\left\{N \sum X^{2}-\left(\sum X\right)^{2}\right)\left(N \sum Y^{2}-\left(\sum Y\right)^{2}\right\}}}
$$

Keterangan :

$$
\begin{array}{lll}
r_{x y} & = & \text { koefisien korelasi antara skor item dengan skor total } \\
\mathrm{X} & = & \text { skor item } \\
\mathrm{Y} & = & \text { skor total } \\
\mathrm{N} & = & \text { banyaknya subyek }
\end{array}
$$

Kriteria r-hitung kemudian dikonsultasikan dengan r-tabel pada taraf signifikan 5\%. Jika r-hitung > r-tabel, item dinyatakan valid.

b) Uji Reliabilitas

Uji Reabilitas dalam penelitian ini dilakukan dengan menggunakan rumus Alpha. Penggunaaan rumus ini didasarkan pada alasan karena skor yang diperoleh bukan 1 dan 0 , tetapi 1 sampai dengan 4 .

Rumus yang digunakan adalah:

$$
r_{11}=\left[\frac{k}{k-1}\right]\left[1-\frac{\sum \sigma_{b}^{2}}{\sigma_{t}^{2}}\right]
$$

(Suharsimi Arikunto, 2010: 239)

Keterangan :

$$
\begin{array}{lll}
\boldsymbol{r}_{\mathbf{1} 1} & = & \text { reliabilitas instrumen } \\
\mathrm{k} & = & \text { banyaknya butir pertanyaan } \\
\sum \sigma_{b^{2}} & = & \text { jumlah varians butir } \\
\sigma_{t}^{2} & = & \text { varians total }
\end{array}
$$


Rumus varian butir dan varian total adalah sebagai berikut :

Varians butir

$$
\sigma_{b^{2}}=\frac{\sum X^{2}-\frac{\left(\sum X\right)^{2}}{n}}{n}
$$

Varians total

$$
\sigma_{t}^{2}=\frac{\sum Y^{2}-\frac{\left(\sum Y\right)^{2}}{n}}{n}
$$

Keterangan :

$$
\begin{array}{lll}
\sigma_{b^{2}} & = & \text { Varians butir } \\
\sigma^{2}{ }_{t} & = & \text { Varians total } \\
\mathrm{X} & = & \text { Skor butir } \\
\mathrm{Y} & = & \text { Skor total } \\
\mathrm{N} & = & \text { Jumlah subyek }
\end{array}
$$

Hasil r-hitung kemudian dikonsultasikan dengan r-tabel pada taraf signifikansi 5\%. "Jika r-hitung > r-tabel, instrumen dikatakan reliabel dan jika r-hitung < r-tabel instrumen dikatakan tidak reliabel”.

Data penelitian ini dianalisis dengan teknik statistik, yaitu menggunakan rumus "regresi dua predictor". Rumus bangun analisis regresi dua predictor tersebut adalah sebagai berikut :

$$
R_{y(1,2)}=\sqrt{\frac{a_{1} \sum x_{1} y+a_{2} \sum x_{2} y}{\sum y^{2}}}
$$

(Suharsimi Arikunto, 2009: 385) 
Keterangan :

$$
\begin{array}{ll}
R_{y(1,2)} & =\text { Koefisien korelasi antara } \mathrm{Y}_{\text {dengan }} \mathrm{X}_{1} \text { dan } \mathrm{X}_{2} \\
\boldsymbol{a}_{1} & =\text { Koefisien prediktor } \mathrm{X}_{1} \\
\boldsymbol{a}_{2} & =\text { Koefisien prediktor } \mathrm{X}_{2} \\
\sum x_{1} y & =\text { Jumlah produk antara } \mathrm{X}_{1} \text { dan } \mathrm{Y} \\
\sum x_{2} y & =\text { Jumlah produk antara } \mathrm{X}_{2} \text { dan } \mathrm{Y} \\
\sum y^{2} & =\text { Jumlah kuadrat kriterium } \mathrm{Y}
\end{array}
$$

Untuk menguji keberartian koefisien regresi secara keseluruhan digunakan uji $\mathrm{F}$ dengan rumus:

$$
F_{\text {reg }}=\frac{R^{2}(n-m-1)}{m\left(1-R^{2}\right)}
$$

(Suharsimi Arikunto, 2009: 453)

Keterangan :

$\begin{array}{lll}\text { Freg } & = & \text { Harga } \mathrm{F} \text { garis regresi } \\ \mathrm{N} & = & \text { Banyak anggota sampel } \\ \mathrm{m} & = & \text { Banyak prediktor } \\ \mathrm{p} R & = & \text { Koefisien korelasi antara kriterium dengan } \\ & & \text { prediktor-prediktor }\end{array}$

\section{HASIL PENELITIAN}

\section{Deskripsi Data}

Data penelitian tentang pengaruh self efficacy dan kecerdasan emosi terhadap motivasi berprestasi siswa SMK PGRI 1 Madiun, pada lampiran 12, 13, dan 14 yang dianalisis dengan bantuan program 
Microsoft Office Excel 2007, maka data penelitian dapat dideskripsikan sebagai berikut:

a) Deskripsi Data Self Efficacy

Berdasarkan hasil skala yang disebarkan kepada responden tentang Self Efficacy siswa SMK PGRI 1 Madiun, diperoleh hasil Mean $=82,294$, Median $=80,917$, Modus $=78,163$, Standar Deviasi $=0,563$, Nilai Minimum =43, Nilai Maximum $=106$.

b) Deskripsi Data Kecerdasan Emosi

Berdasarkan hasil skala yang disebarkan kepada responden tentang kecerdasan emosi siswa SMK PGRI 1 Madiun, diperoleh hasil Mean $=79,716$, Median $=79,17$, Modus $=78,078$, Standar Deviasi $=8,691$, Nilai Minimum $=49$, Nilai Maximum $=114$.

c) Deskripsi Data Motivasi Berprestasi

Berdasarkan hasil skala yang disebarkan kepada responden tentang motivasi berprestasi siswa SMK PGRI 1 Madiun, diperoleh hasil Mean $=83,206$, Median $=82,75$, Modus $=81,838$, Standar Deviasi $=9,692$, Nilai Minimum $=42$, Nilai Maximum $=110$.

\section{Simpulan Hasil Pengujian Hipotesis}

Berdasarkan hipotesis penelitian, maka dalam penelitian ini dikemukakan simpulan pengujian hipotesis sebagai berikut:

1) Ada Pengaruh Self Efficacy Terhadap Motivasi Berprestasi Siswa SMK PGRI 1 Madiun Tahun Pelajaran 2013/ 2014.

2) Ada Pengaruh Kecerdasan Emosi Terhadap Motivasi Berprestasi Siswa SMK PGRI 1 Madiun Tahun Pelajaran 2013/ 2014.

3) Ada Pengaruh Secara Simultan Self Efficacy dan Kecerdasan Emosi Terhadap Motivasi Berprestasi Siswa SMK PGRI 1 Madiun Tahun Pelajaran 2013/ 2014. 


\section{E. SIMPULAN DAN SARAN}

\section{Simpulan}

Berdasarkan penelitian yang telah dilaksanakan diperoleh simpulan sebagai berikut:

1) Ada Pengaruh Self Efficacy Terhadap Motivasi Berprestasi Siswa SMK PGRI 1 Madiun.

2) Ada Pengaruh Kecerdasan Emosi Terhadap Motivasi Berprestasi Siswa SMK PGRI 1 Madiun.

3) Ada Pengaruh Secara Simultan Self Efficacy dan Kecerdasan Emosi Terhadap Motivasi Berprestasi Siswa SMK PGRI 1 Madiun.

\section{Saran}

Bertolak dari simpulan sebagaimana yang telah dijelaskan di atas, maka dikemukakan saran-saran sebagai berikut :

1) Guru dan Konselor

Diharapkan selalu memberikan motivasi terhadap siswa agar mampu meningkatkan efikasi diri serta dapat belajar mengendalikan emosi dengan baik.

2) Orang Tua

Orang tua berperan dalam mendampingi putra-putrinya dalam meningkatkan efikasi diri dan mengembangkan kecerdasan emosi agar siswa termotivasi dalam menghadapi tuntutan-tuntutan yang ada di lingkungan sekitar.

3) Siswa

Agar siswa dapat termotivasi untuk meningkatkan keyakinan diri yang positif dalam menghadapi tuntutan-tuntutan yang ada serta menggunakan kecerdasan emosi dalam situasi apapun.

4) Pengembangan Ilmu Pengetahuan

Diharapkan dapat menambah teori dan konsep psikologi terutama bagi bimbingan dan konseling mengenai self efficacy dan kecerdasan emosi terhadap motivasi berprestasi siswa. 


\section{DAFTAR PUSTAKA}

Abdul Rahman Barakatu. 2007. Membangun Motivasi Berprestasi: Pengembangan Self Efficacy dan penerapannya dalam dunia pendidikan. Lentera Pendidikan (Online). Jilid 5, No. 1, (Error! Hyperlink reference not valid., Diunduh 10 Februari 2014).

David G.Myers. 2012. Psikologi Sosial. Jakarta: Salemba Humanika.

Dede Rahmat Hidayat. 2011. Teori dan Aplikasi. Psikologi Kepribadian dalam Konseling. Bogor: Ghalia Indonesia.

Djaali. 2012. Psikologi Pendidikan. Jakarta: PT. Bumi Aksara. 2009. Psikologi Pendidikan. Jakarta: PT. Bumi Aksara.

Dendik Surya Wardana. 2013. Motivasi Berprestasi dengan Kinerja Guru yang Sudah Disertifikasi. Jurnal Ilmiah Psikologi Terapan. Jilid 1, No. 1, (http://ejournal.umm.ac.id, Diunduh 11 Februaru 2014).

Goleman D. 2005. Emotional Intelligence. Kecerdasan Emosional. Mengapa EI Lebih Penting Daripada IQ. Jakarta: PT Gramedia Pustaka Utama.

Harfiahana Puspa Rini. 2013. Self Efficacy Dengan Kecemasan Dalam Menghadapi Ujian Nasional. Jurnal Online Psikologi. Jilid 1, No. 1, (http://ejournal.umm.ac.id, Diunduh 10 Februari 2014).

Imam Musbikin. 2013. Mengatasi Kenakalan Siswa Remaja. Pekanbaru Riau: Zanafa Publishing.

John W. Santrock. 2003. Adolescence. Jakarta: Erlangga.

Juliansyah Noor. 2011. Metodologi Penelitian. Jakarta: Kencana Prenada Media Group.

Laura A.King. 2012. Psikologi Umum. Sebuah Pandangan Apresiatif. Jakarta: Salemba Humanika.

M. Nur Ghufron dan Rini Risnawita S. 2010. Teori-teori Psikologi. Yogyakarta: Ar-Ruzz Media.

Makmun Khairani. 2013. Psikologi Umum. Yogyakarta: Aswaja Pressindo.

Ratna Wulan. 2011. Mengasah Kecerdasan Pada Anak. (Bayi - Pra-sekolah). Yogyakarta: Pustaka Belajar.

Rumiani. 2006. Prokrastinasi Akademik ditinjau Dari Motivasi Berprestasi dan Stres Mahasiswa. Jurnal Psikologi Universitas Diponegoro. Jilid 3, No. 2, (http://ejournal.undip.ac.id, Diundih 11 Februaru 2014).

Saifuddin Azwar. 2011. Penyusunan Skala Psikologi. Yogyakarta: Pustaka Pelajar.

Singgih D.Gunarsa. 2004. Psikologi Praktis:Anak, Remaja, dan Keluarga. Jakarta: PT. BPK Gunung Mulia.

Sofyan S. Wilis. 2012. Psikologi Pendidikan. Bandung: CV Alfabeta.

Sugiyono. 2010. Metode Penelitian Pendidikan. Bandung: CV Alfabeta. 2012. Metode Penelitian Kuantitatif Kualitatif dan R\&D. Bandung:

CV Alfabeta.

2013. Metode Penelitian Kuantitatif Kualitatif dan R\&D. Bandung:

CV Alfabeta.

Suharsimi Arikunto .2006. Prosedur Penelitian Suatu Pendekatan Praktik. Jakarta: PT. Rineka Cipta. 2009. Manajemen Penelitian. Jakarta: PT. Rineka Cipta. .2010. Prosedur Penelitian Suatu Pendekatan Praktik. 
Jakarta: PT. Rineka Cipta.

V. Teguh Suharto. 2011. Perbedaan Keefektifan Model pembelajaran Experiential Learning, Sinektik, dan Pengajaran Langsung dalam Pembelajaran Apresiasi Prosa Fiksi Ditinjau dari Kecerdasan Emosional Siswa. Eksperimen pada Sekolah Menengah Pertama di Jawa Timur, 17 (2):130157. 